Наталія ЛЕПУХОВА, orcid.org/0000-0001-7476-559X кандидат філологічних наук, доиент кафедри німеиької мови Ніжинського державного університету імені Миколи Гоголя (Ніжин, Чернігівська область, Україна) lepисhowa_nat@ukr.net

\title{
ПЕРЕКЛАД НІМЕЦЬКИХ АГРАРНИХ ТЕРМІНІВ-КОМПОЗИТІВ УКРАЇНСЬКОЮ МОВОЮ
}

\begin{abstract}
Статтю присвячено дослідженню особливостей перекладу термінів-композитів аграрної тематики 3 німецької мови українською мовою.

Розвиток суспільства та його прогрес в окремих галузях суспільної діяльності відтворюється безпосередньо в мові. Суспільні процеси та поняття отримують свою номінацію в мові, збагачуючи і розвиваючи ії, а мова своєю чергою організовує і структурує наукове пізнання, називаючи нові предмети і поняття і створюючи терміносистеми для окремих наукових галузей. Між мовою та наукою існує нерозривний зв'язок: наука використовує весь матеріал загальної мовної системи, маючи своїми базовими поняттями терміни. Терміни повинні бути сталими, однозначними, свідомо вживатися спеціалістами в мовленні, мати конкретне лексичне значення і практичне застосування, тому питання вивчення термінів із конкретної наукової галузі в лінгвістиці, особливостей їх перекладу з метою міжмовної уніфікації є актуальними в наш час.

У межах розвитку міжнародного співробітництва України з європейськими крайнами особливо велике значення має аграрна сфера як одна з провідних економічних галузей України, тому дослідження мови міжнародного спілкування фахівців иієё галузі економіки та перекладацьких можливостей для поліпшення такої міжнародної співпраці є підгрунтям для иієї статті.

У статті осмислюються й узагальнюються терміни, щзо існують у сфері сільського господарства, на матеріалі німецької мови наводяться приклади найбільш частотних аграрних термінів-композитів у сучасній теоретичній і практичній літературі, аналізуються особливості їх перекладу украӥнською мовою для вирішення завдань практичного і навчального спрямування, визначаються основні прийоми перекладу аграрних термінівкомпозитів із німеиької мови украӥнською мовою.
\end{abstract}

Ключові слова: переклад, терміни-композити, аграрна лексика, прийоми перекладу.

Nataliia LIEPUKHOVA, orcid.org/0000-0001-7476-559X

Candidate of Philological Sciences, Associate Professor at the Department of German Language

Nizhyn Mykola Gogol State University (Nizhyn, Chernihiv region,Ukraine) lepuchowa_nat@ukr.net

\section{TRANSLATION OF GERMAN AGRICULTURAL TERMS-COMPOSITES INTO UKRAINIAN LANGUAGE}

The article researches peculiarities of translating agrarian composite terms from German into Ukrainian.

Society development and its progress in certain spheres of social activities are reflected in the language. Social processes and concepts are denominated in the language, enriching and developing it, while the language arranges and structures scientific knowledge by naming new objects and concepts and creating terminological systems for individual scientific fields. There is an inextricable link between language and science: science uses all common language resources with terms as its basic concepts. Terms must be unchangeable, unambiguous, consciously used by specialists in their speech, they must have a specific lexical meaning and practical application. Therefore, in modern linguistics, the study of terms in a specific scientific field, peculiarities of their translation for interlanguage unification are especially relevant.

The agrarian sector is particularly important in the development of international cooperation between Ukraine and European countries, as it is one of the leading economic sectors in Ukraine. Therefore, the study of the language of international communication between specialists in this industry and translation opportunities to improve such cooperation constitute the basis of this article.

The article discusses and summarizes terms that exist in the field of agriculture; gives examples of the most frequent agricultural composite terms in modern German theoretical and practical literature; analyzes peculiarities of their translation into Ukrainian to solve practical and educational challenges; determines the main techniques in the translation of agricultural composite terms from German into Ukrainian.

Key words: translation, composite terms, agrarian vocabulary, translation techniques. 
Постановка проблеми. У наш час правильність та адекватність перекладу аграрної термінології $\epsilon$ запорукою забезпечення економічної стабільності країни на міжнародній арені на фоні зростання кількості міжнародних контактів і зовнішньоекономічних зв'язків в аграрній галузі, проводяться реформи у сфері аграрної політики із залученням і запозиченням досвіду іноземних країн, у тому числі і німецькомовних. Оскільки у філологічному плані німецька аграрна промисловість послуговується великою кількістю термінів-композитів, їх переклад українською мовою має велике значення для розвитку власного аграрного сектора. Перекладач для адекватного перекладу термінології має володіти певною сумою знань із тієї галузі, до якої належить відповідна терміносистема.

Аналіз досліджень. Аналіз різних досліджень, присвячених проблемам термінології, показує, що терміни стають об'єктом дослідження як спеціалістів різних наукових спеціальних галузей, так і лінгвістів. Терміни досліджуються 3 точки зору їх відповідності науково-технічним поняттям, на позначення яких вони використовуються, робляться спроби стандартизації та уніфікації термінів і впорядкування різних терміносистем. Науково-технічні термінологічні енциклопедичні словники укладаються зазвичай фахівцями певної галузі наукового пізнання з метою систематизації термінології цієї галузі і представлення дефініцій термінів, які входять до ії складу.

Першими дослідниками вітчизняної термінологічної школи були Д. С. Лотте, В. В. Виноградов, Г. О. Винокур, О. О. Реформатський, О. С. Герд, В. П. Даниленко та ін., які зробили великий внесок у сферу дослідження і розвитку термінології. Системному вивченню науки про терміни присвячено роботи Ф. А. Циткіної, Т. А. Журавльової. Проблеми мовної природи термінів висвітлюються у працях А. I. Моісеєва. Термін як особливу лексичну одиницю розглядають Р. Ю. Кобрин, В. Н. Лейчик і Т. А. Лисицина. А. В. Суперанська досліджує терміни з точки зору лексикографічного опису. У багатьох лінгвістичних дослідженнях розкриваються питання утворення термінів (Я. А. Кліновицький, В. С. Кулебакін). У монографії А. С. Д'якова, Т. Р. Кияка, 3. Б. Куделька «Основи термінотворення: семантичні та соціолінгвістичні аспекти» досліджуються лінгвістичні та екстралінгвістичні чинники стосовно ïx безпосереднього чи опосередкованого впливу на будову та стандартизацію термінів у межах національних терміносистем, їхню зовнішню і внутрішню форми, визначаються шляхи термінологічного планування в аспекті соціолінгвіс- тики, вивчається роль свідомого та підсвідомого в модернізації та стандартизації лексичного складу мови, як соціолінгвістичний фактор у формуванні розглядаються мовні інтерференції.

Так само і в зарубіжній лінгвістиці багато досліджень присвячено загальним питанням словотворення, термінології і фахових мов, зокрема, у роботах німецьких лінгвістів В. Фляйшера, Л. Гофмана, В. Доналіса досліджуються основні принципи утворення слів сучасної німецької мови, в тому числі побудови складених іменників, основного шару лексики в науковій термінології. В. Шмідт досліджує фахові мови 3 точки зору їх виникнення, розвитку і функціонування в суспільстві, проводить прямий зв'язок між науково-технічним процесом і виникненням нових термінів. $\mathrm{У}$ роботах В. Рейнхарда досліджуються технічні терміни, їх класифікація, побудова, основні принципи поєднання словотвірних основ у межах складеного терміна. Основні питання термінології в галузі сільського господарства (визначення поняття «термін», класифікація аграрних термінів, моделі побудови) досліджуються в праці Л. Дрозд. Стосовно досліджень зарубіжними науковцями особливостей перекладу німецьких термінів композитів існують компаративні дослідження на матеріалі німецької і англійської, чеської, словацької, іспанської, італійської мов у різних галузях науки. Дослідження перекладу німецьких аграрних термінів-композитів українською мовою зарубіжними вченими не проводилися.

Мета статті полягає в комплексному вивченні особливостей функціонування і перекладу німецьких термінів-композитів аграрної тематики.

Викладосновногоматеріалу.Основоютерміна $\epsilon$ наукова дефініція або конвенція, і термін варто розуміти як номінацію наукових понять. Термін $\epsilon$ частиною фахової мови. На відміну від слів звичайної лексики, про відповідність терміна роблять висновок не лише мовознавці, а й науковці відповідної наукової чи технічної предметної галузі.

Є різноманітні класифікації термінів, які на передній план висувають їхні різні ознаки. Так, наприклад, Л. Гофман до найважливіших ознак термінів зараховує об'єктивність, логіку, прозорість, зрозумілість, які виявляються, перш за все, на лексичних і синтаксичних прикладах (Hoffmann, 1984: 69). Вайсбергер вважає терміни особливими лексичними одиницями, які прагнуть до однозначності i впорядкованості понять (Weisberger, 1954: 213). Уле пише, що терміни характеризуються відмовою від образності, демонстративності, експресивності і різноманіття задля ясності і об’єктивності (Ule, 1960: 363). 
Різноманітні підходи до визначення поняття «термін» опираються на різні характеристики термінів, які для науковців виступають на передній план в процесі аналізу їхньої суті. Такими характеристиками термінів $\epsilon$ дефінітивність, функціональність, однозначність, системність, науковість, точність, стислість, нейтральність.

У лінгвістиці композиція разом із деривацією, конверсією, скороченням слів, створенням абревіатур, редуплікацією і контамінацією є одним із способів словотворення. У німецькій мові композиція або словоскладання - найбільш поширений спосіб утворення нових слів, а отже, нових термінів. Він належить до комбінованих видів словотворення. «При використанні композиції композити складаються переважно зі слів і конфіксів» (Donalies, 2007: 35). Композити мають бінарну структуру, яку утворюють їх самостійні компоненти. У фахових мовах композиція є продуктивним способом творення субстантивованих термінів. За допомогою використання композитів досягається спрощення мовлення. Крім того, у фаховій термінології композити $є$ простим і безпосереднім способом творення й організації родових і видових понять.

У широкому значенні композити характеризуються як морфемні конструкції, компоненти яких можуть виступати вільними морфемами або утворювати морфемні конструкції, що можуть об'єднуватися в одне слово (Fleischer, 1983: 53). Степанова і Фляйшер поділяють терміни-композити на детермінативні і копулативні. Детермінативні терміни-композити існують на основі відношення підпорядкування (субординації), а копулативні терміни-композити виникають на основі взаємозв'язку (координації). За твердженням Доналіс, детермінативні терміни-композити складаються 3 основного і залежного слова (Donalies, 2007: 36). Степанова і Фляйшер вказують на розвиток у термінах-композитах спеціального поняття із загального (Stepanova, Fleischer, 1985: 110). Для детермінативних термінів-композитів німецької мови порядок компонентів у терміні відіграє вирішальну роль у процесі розкриття його значення, зі зміною порядку компонентів змінюється значення слова. Граматичні категорії (роду, числа, відмінка) визначаються за другим компонентом, який у відношенні підпорядкованості виступає основним словом, наприклад, die Würmer - die Regenwürmer (мн.), das Gut - das Saatgut (cep.p.), die Untersuchung - die Bodenuntersuchung (жін.p.) тощо. Елементи копулативних термінів-композитів можуть заміщувати один одного, що не впливає на значення терміна, наприклад, die Pflugscheibe - der Scheibenpflug.
Сучасні дослідники термінів-композитів виділяють такі їх формальні ознаки: 1) суцільна формантність - неподільність на самостійні частини і неможливість розміщення між компонентами композита інших одиниць лексичного рівня; 2) відсутність паузи між складовими елементами композита; 3) неможливість граматичної зміни першого компонента без суттєвої зміни лексичного значення всього композита; 4) неможливість перестановки компонентів композита (Талалай, 2011: 26-28).

Перелік причин утворення композитів було запропоновано П. Поленцем. Серед таких причин він виділяе номінацію (відсутність необхідного найменування), універбацію багаточленних конструкцій; міцне закріплення в свідомості (використання семантично мотивованих слів, оскільки вони міцно і легко закріплюються у свідомості), мовну економію (бажання мовців уникати громіздких конструкцій), посилення вираження, застарілість якоїнебудь номінативної одиниці, втрату ії наочності (der Strommarkt замість der Elektrizitätsmarkt), утворення за аналогією (Polenz, 1973: 158).

Узагальнюючи все зазначене вище, ми можемо дати таку дефініцію термінів-композитів: терміни-композити - це спеціальні слова на позначення певних понять спеціальної наукової галузі, які характеризуються функціональністю, системністю, однозначністю, науковістю, стислістю, нейтральністю і утворені на основі словоскладання.

Як зазначає М. Д. Степанова, «словоскладання - це один із найстаріших і одночасно один із найбільш продуктивних способів словотворення іменників у німецькій мові» (Степанова, 2007: 109). У результаті словоскладання, як ми вже зазначали вище, утворюється композит як «самостійна граматично і семантично єдина лексична одиниця, яка $\epsilon$ частиною словникового запасу мови і в реченні може виступати в ролі головного або другорядного члена речення» (Прошина, 2002: 52).

У нашому дослідженні ми розглядаємо терміни-композити як складні слова, що використовуються для номінації певних понять у сфері сільського господарства і утворені шляхом складання двох і більше самостійних слів, їхніх основ та кореневих морфем. В основі побудови таких термінів лежать композиційно-логічні зв'язки. Так, наприклад, логічно обгрунтованим є німецький складений іменник das Warmwasser і його компоненти можуть вступати між собою в композиційні відносини, що неможливо при побудові за тією ж моделлю іменника der Warmschnee тощо (Нагамова, 2007: 90-94). 
Виділені аграрні терміни-композити ми класифікували за різними критеріями: а) за кількістю твірних основ; б) за типом граматично-синтаксичних зв'язків між компонентами; в) за генетичними джерелами походження твірних елементів.

Залежно від кількості окремих слів чи кореневих морфем, що утворюють аграрні терміникомпозити, ми поділяємо їх на двокомпонентні, трикомпонентні та багатокомпонентні композити. При цьому найбільш вживаними є двокомпонентні терміни-композити, їх частка в корпусі досліджуваних лексичних одиниць загальною кількістю 610 лексичних одиниць, відібраних методом суцільної вибірки із німецького періодичного видання «Аграрцайтунг» та «Аграрного енциклопедичного словника 3 найважливішими поняттями сільського господарства для європейської місцевості» (пер. 3 нім. мови - автора) 2017 р., становить 521 лексичну одиницю, або $85,41 \%$. На другому місці зі значенням 81 лексична одиниця, або $13,28 \%$, знаходяться трикомпонентні лексичні одиниці. Чотирикомпонентні аграрні терміни-композити представлені у дослідженні лише 6 лексичними одиницями, що становить $0,98 \%$, і п'ятикомпонентні займають останне місце 3 кількістю 2 лексичні одиниці і відсотковим показником $0,33 \%$ відповідно.

Терміни-композити в німецькій аграрній термінології вживаються через відсутність необхідної номінації. Також носії мови надають перевагу семантично мотивованим словам, які легко закріплюються у свідомості, наприклад: die Blattlaus, der Blachfrost, der Blattkohl. Ще одним мотивом утворення композитів $\epsilon$ мовна економія, наприклад: der EU-Markt, die H-Milch, die Pflanzenschutz-Sachkundeverordnung.

Як ми виявили під час дослідження, двокомпонентні терміни-композити в німецькій аграрній термінології $є$ найбільш чисельними, що ми пояснюємо більшою простотою поєднання двох компонентів в одне слово, аніж трьох і більше, 3 точки зору граматично-семантичних зв'язків у слові. Проте варто зауважити, що німецькі двокомпонентні аграрні терміни-композити здатні до утворення так званих «термінологічних гнізд», коли шляхом приєднання до них ще одного компонента отримуємо щоразу нове значення слова 3 уточненням перших двох компонентів, наприклад: Palmöl (n) - пальмова олія $\rightarrow$ Palmölimport (m) - імпорт пальмової олії, Palmölkurs (m) - курс пальмової олії, Palmölmarkt (m) - ринок пальмовоі олії, Palmölnotierung (f) - котирування пальмової олії, Palmölpreis (m) - ичіна на пальмову олію, Palmölproduktion (f) - виробництво пальмової олії. Відповідно до вказаного прикладу термінологічним гніздом є термін-композит Palmöl, а всі наступні композити, утворені на його основі шляхом додавання додаткових компонентів, є окремими термінами-композитами, які конкретизують вихідний елемент.

У німецькій аграрній терміносистемі у сфері землеробства найбільш частотними $є$ такі компоненти термінів-композитів: Acker- (Ackerbau, Ackerfläche, Ackerland), Boden-(Bodenart, Bodenbearbeitung, Bodenfeuchtigkeit), Feld- (Feldfutterbau, Feldgehölz, Feldhäcksler), Land- (Landmaschine, Landwaren, Landwirt). У сфері рослинництва найчастіше зустрічаються такі компоненти німецьких аграрних термінів-композитів: -Früchte (Hackfrüchte, Halmfrüchte, Hülsenfrüchte), -Kultur (Industriekultur, Monokultur, Sonderkultur), -Pflanze (Futterpflanze, Hauptkulturpflanzen, Hybridpflanze), -Saat- (Mulchsaat, Nachsaat, Saatgut). У сфері тваринництва найбільш вживаними у творенні термінів-композитів є такі компоненти: -Stall (Abferkelstall, Anbindestall, Hühnerstall), -Zucht- (Schafzucht, Tierzucht, Zuchtbestand). У сфері аграрної економіки та аграрної політики найчастіше зустрічаються такі морфеми: Agrar(Agrarbericht, Agrarfond, Agrarhandel), Betrieb(Betriebseinkommen, Betriebsform, Betriebsfläche), Bio- (Biodiesel, Biodiversität, Biomasse, Biotechnik), -Markt- (Agrarmarkt, Marktordnung, Weltmarkt), -Wirtschaft- (Wirtschaftsaufschwung, Wirtschaftsdünger, Dreifelderwirtschaft). Ми вважаємо, що частотність вживання саме цих компонентів термінологічних композитних одиниць зумовлена специфікою відповідних сфер агропромислового комплексу.

Відповідно до типу граматично-синтаксичних зв'язків між компонентами німецьких аграрних термінів-композитів усі досліджувані нами терміни-композити $\epsilon$ детермінативними композитами, тобто між їхніми компонентами виникає зв'язок підпорядкованості, коли останній компонент терміна $є$ основним, а попередні використовуються для його уточнення і в разі зміни порядку розташування компонентів змінюється значення слова, наприклад: Kopfkohl (m) - капуста качанна (як сорт капусти) і Kohlkopf (m) - качан капусти (як частина рослини).

У процесі перекладу термінів найчастіше використовують лексичний еквівалент терміна, тобто постійну лексичну відповідність, яка точно відповідає значенню терміна. Лексичними еквівалентами $\epsilon$, наприклад, назви рослин: Ackerhahnenfu $\beta$ (m) - жовтець, Ackerschachtelhalm (m) - хвош польовий, Ackerwind (f) - берізка, Birnbaum 
(m) - груша, Brennessel (f) - кропива, Buchweizen (m) - гречиха, інші терміни, наприклад: Bodenleben (n) - едафон, Brandmarkung $(f)$ - таврування, Brandzeichen (n) - клеймо, Fachagrarwirt (m) - зоотехнік тощо. Проте загальновідомо, що постійних еквівалентів небагато і в різних терміносистемах терміни можуть набувати різних значень. Якщо говорити про переклад німецьких аграрних термінів українською мовою, то завдання складання двомовного словника таких термінів лише стоїть перед науковцями, тому, перекладаючи німецькі терміни-композити, варто враховувати їхні словотвірні і структурні моделі, рівень узуальності/оказіональності.

Крімлексичних еквівалентів, однимізнайпоширеніших прийомів перекладу складених термінів аграрної тематики $є$ калькування або поморфемний переклад терміна-композита. При цьому може зберігатися структура німецького слова в україномовному перекладі і аграрний термін-композит німецькою мовою буде передаватися відповідними засобами української мови одним словом, наприклад: Ackerbau (m) - землеробство, Benzinleitung $(f)$ - бензопровід, Bodenkunde (f) - трунтознавство, Bodennutzung (f) - землекористування, Düngerstätte (f) - гноєсховище, Gasbeständigkeit (f) - газостійкість, Gasumtausch - газообмін, Grasanbau (m) - травосіяння, Grasbestand(m) mpавостіü, Kraftwagenanhänger (m) - автоприyin, Miststreuеr (m) - гноєрозкидач, Staatshaushalt (m) - держбюджет , Tonerde (f) - глинозем, Stresstoleranz $(f)$ - cmресостійкість та ін.

$\mathrm{У}$ певних випадках для перекладу аграрних термінів-композитів із німецької мови українською мовою застосовують транскодування, тобто буквенну або фонемну передачу термінів вихідної мови 3 допомогою алфавіту мови перекладу. Виділяють чотири види транскодування:

1) транскрибування - відтворення звукової форми слова вихідної мови 3 допомогою літер мови перекладу: Heterogen - гетероген, Homogen - гомоген, Biogas (n) - біогаз; Mikroelement (n) - мікроелемент;

2) транслітерування - відтворення графічної форми слова вихідної мови 3 допомогою літер мови перекладу: Protoplast - nротопласт;

3) змішане транскодування - транскрибування 3 елементами транслітерування: Genotyp (m) - генотип, Phänotyp (m) - фенотип, Karyotyp (m) - карiomun;

4) адаптивне транскодування - пристосування вихідної форми слова до фонетичних та/або граматичних норм мови перекладу: Heterozygote (f) - гетерозигота, Hoтоzygote (f) - гомозигота,
Rhizosphäre (f) - puзосфера, Mykotoxine (Pl) мікотоксини, Monokultur (f) - монокультура.

Якщо в німецьких аграрних термінах-композитах першими компонентами виступають такі елементи, як Agro-, Bio-, Homo-, Hetero-, Mikro-, Mono-, Phäno-, Hydro-, Makro- тощо, то в таких складених термінах перший компонент відтворюється українською мовою шляхом транскрибування, а наступні - 3 допомогою калькування, структура вихідного слова при цьому зазвичай зберігається, наприклад: Agrobakterium (n) - агробактерія, Agrochemie (f) - агрохімія, Agrophysik (f) - агрофізика, Biomasse (f) - біомаса, Biotechnik (f) - біотехніка, Mikroklima (n) - мікроклімат, Mikroorganismen (Pl) - мікроорганізми, Makrö̈konomik - макроекономіка, Hydropuтре гідронасос і т.д.

Проте найбільш поширеним перекладацьким прийомом у процесі відтворення німецьких аграрних термінів-композитів українською мовою $€$ калькування без збереження вихідної структури терміна $з$ допомогою словосполучення. При цьому можна виділити такі види словосполучень у процесі перекладу двокомпонентних термінів:

1) прикметник + іменник: Pflanzgut (n) - посадковий матеріал, Phosphatdünger (m) - фосфатне добриво, Produktionskosten (Pl) - виробничі затрати, Rauhfutter (n)-грубий корм, Referenzpreis (m) - довідкова иіна, Saatgut (n) - посівне насіння, Schutzkleidung $(f)$ - захисний одяг та ін.;

2) іменник у називному відмінку + іменник у родовому відмінку: Pflanzenschutz $(m)-$ захисm рослин, Qualitätskontrolle (f) - контроль якості, Schadschwelle $(f)$ - поріг шкідливості, Schweinepest (f) - чума свиней, Sproßspitze (f) - верхівка паростка, Taupunkt (m) - точка танення та ін.;

3)іменник+прийменник+іменник:Trogfütterung (f) - годівля з корита, Schadensversicherung (f) страхування від збитків, Reparaturkosten (Pl) витрати на ремонт, Qualitätsprämie (f) - премія за якість, Maschinenhalle (f) - навіс для машин та ін.;

4) іменник + прикметник + іменник: Schrottmehl (n) - борошно грубого помолу, Rinderrasse (f) порода великої рогатої худоби, Reserveländereien $(\mathrm{Pl})$ - землі державного запасу та ін.;

5) іменник-іменник: Abferkelstall (m) - свинарник-маточник, Futterautomat (m) - годівниияавтомат, Mähhächsler (m) - косарка-подрібнювач, Zeigerpflanze (f) - рослина-індикатор та ін.

Iз наведених вище прикладів ми можемо зробити висновок про застосування граматичних трансформацій у процесі перекладу німецьких аграрних термінів-композитів, а саме заміни частин мови та перестановки компонентів терміна, 
які є регулярними трансформаціями і викликані нормами мови перекладу.

У процесі перекладу німецьких аграрних термінів-композитів використовуються також і лексичні заміни, особливо це стосується першого компонента терміна, який $є$ детермінуючим стосовно основного компонента, наприклад, у складеному терміні Kartoffelkäfer $(m)$ у перекладі перший компонент Kartoffel замінюється на колорадський і в перекладі отримуємо звичне колорадський жук, бо виразу «картопляний жук» немає в українській аграрній термінології. Лексичні заміни в процесі перекладу термінів виникають тоді, коли інша лексична одиниця здатна краще передати значення терміна або якщо інша лексична одиниця більше підходить до культури мови перекладу. Останнє спостерігаємо особливо в процесі перекладу образних термінів-композитів аграрної тематики, побудованих на метафорі або за аналогією, з німецької мови українською мовою. Розглянемо, наприклад, німецькомовну назву рослини Hundszahn (m). Відповідник українською мовою звучить «свинорий». Тут відбулася лексична заміна обох компонентів німецького складеного іменника, що ми можемо пояснити лінгвокультурними особливостями творення назв рослин українською мовою. Німецький термінкомпозит Mehltau (f) на позначення хвороби рослин може перекладатися українською мовою традиційно $з$ допомогою калькування як мучниста роса або шляхом лексичної заміни з переосмисленням образу як попелиия.

Іншим видом лексико-граматичних трансформацій, який використовується під час перекладу, є додавання 3 метою уточнення термінів українською мовою для їх кращого розуміння носієм української мови і природності звучання: Grünsilage (f) - силос зелених кормів, Sortenschutz (m) - захист нових сортів рослин, Spätlese (f) - пізній збір винограду, Regentonne (f) - бочка для дощяової води, Reinheitsgebot (n) Закон про чистоту пива, Hybridmais (m) - гібридний сорт кукурудзи, Totalherbizid (n) - гербіцид загальної діï, Verbraucherschutz (m) - захист прав споживачів, Welternährung $(f)$ - світове забезпечення продуктами харчування.

У деяких прикладах можемо спостерігати логічний розвиток поняття, який супроводжується лексичною заміною i додаванням лексичних одиниць та конкретизацією змісту. Наприклад: Agrarhandel (m) - торгівля сільськогосподарською продукиією - у цьому випадку перший компонент терміна-композита Agrar замінюється і разом із тим створюється вислів, типовий для української мови: «торгівля сільськогосподарською продукиією» замість «аграрна торгівля». Так само і в процесі перекладу терміна-композита Agrarökonomie (f) відбувається заміна компонента Agrar на «сільськогосподарського виробництва» і, відповідно, маємо уточнення змісту - «економіка сільськогосподарського виробництва». Логічний розвиток поняття спостерігаємо також і на прикладі Zweinutzungsrasse (f) - м'ясо-молочна порода, коли відбувається заміна компонента Zweinutzung, що перекладається дослівно як «подвійне використання», на «м'ясо-молочна», тобто зміна процесу на якість.

Протилежною до трансформації додавання є трансформація випущення, коли в перекладі певний компонент терміна-композита випускається через надлишок інформації, яку він несе, наприклад: Holzblock (m) - колода. У цьому випадку в перекладі слово «дерев'яна» у значенні «дерев'яна колода» або “словосполучення «здерева» узначенні «колодаздерева» будезайвим, оскільки і так зрозуміло, що колода - дерев'яна. Інші приклади: Ausgleichszahlung (f) - компенсаuія, Nutzflächenwiedergewinnung $(f)$ - рекультиваиія земель, Mikronährstoffdüngemittel (Pl) - мікродобрива, Nebenerwerbslandwirtschaft $(f)$ - nідсобне господарство.

Інколи в процесі перекладі німецьких аграрних термінів-композитів може використовуватися антонімічний переклад, або конверсивна заміна, - спосіб перекладу, при якому ствердне поняття в мові оригіналу замінюється на заперечне в мові перекладу і навпаки, наприклад: Direktvermarktung $(f)$ - збут без посередників.

Оскільки в українській мові часто відсутні терміни і поняття, які використовуються в німецькій аграрній термінології, доводиться застосовувати описовий переклад або експлікацію. Наведемо кілька прикладів застосування описового перекладу в процесі відтворення деяких німецьких аграрних термінів-композитів, які не мають еквівалентів або відповідників в українській мові та до яких не можна застосувати будь-який інший вид трансформацій: Marktfruchtbetrieb (m) - підприсмство з продажу овочів і фруктів на ринку Lichtkeimer (Pl) - рослини, які проростають тільки на світлі, Anbindestall (m) - примімення для прив'язного утримання худоби, Anwenderschutz (m) - захист робітників, які застосовують добрива, Haupterwerbsbetrieb (m) основна господарська діяльність, спрямована на збільшення прибутку, Aufwandmenge (f) - кількість, яка витрачається, Frosttrocknis (f) - висушення внаслідок дї морозу, Erzeugergemeinschaft 
(f) - об'єднання власників сільськогосподарських або рибодобувних підприємств та ін.

Висновки. Проаналізувавши перекладацькі прийоми в процесі відтворення німецьких аграрних термінів-композитів - переклад за допомогою еквівалентів, калькування, транскодування, лексичних і граматичних замін, перестановок, додавання, випущення, антонімічний і описовий переклад, ми можемо зробити висновок, що найбільш частотним $є$ прийом калькування без збереження структури вихідного терміна-композита і передачі 3 допомогою словосполучення українською мовою - найчастіше узгодження прикметника 3 іменником або іменника в називному відмінку з іменником у родовому відмінку. Під час перекладу безеквівалентних термінів-композитів 3 аграрної проблематики українською мовою найбільш продуктивним видається описовий переклад, який дає змогу точно відтворити зміст позначуваного поняття, хоча і несе певні втрати мовної економії.

\section{СПИСОК ВИКОРИСТАНИХ ДЖЕРЕЛ}

1. Нагамова Н. В. Экзоцентрические композиты в немецком языке. Межвузовский сборник научных трудов: Вестник Ставропольского государственного университета. 2007. Вып. 48. С. 90-94.

2. Прошина 3. Г. Теория перевода: учебник. 2-е изд. Владивосток : ДВГУ, 2002. 240 с.

3. Степанова М. Д. Словообразование современного немецкого языка. Изд. 2-е, испр. Москва : КомКнига, 2007. $376 \mathrm{c}$.

4. Талалай Т. С. Субстантивные определительные композиты в текстах немецкой рекламы : автореф. дис. ... канд. фил. н. : 10.02.04. Уфа, 2011. 288 с.

5. Donalies, E. Basiswissen Deutsche Wortbildung. Tübingen: Narr Francke Attempto Verlag GmbH + Co. KG., 2007. $159 \mathrm{~S}$.

6. Fleischer, W. Wortbildung der deutschen Gegenwartssprache. 1. Aufl. Leipzig: VEB Bibliographisches Institut, 1983. $272 \mathrm{~S}$.

7. Hoffmann, L. Kommunikationsmittel Fachsprache. Eine Einführung. 2. überarbeitete Auflage. Berlin: AkademieVerlag, 1984. $431 \mathrm{~S}$.

8. Polenz, P. Synpleremik I: Wortbildung. Lexikon der germanischen Linquistik. Tübingen: Max Niemeyer, 1973. 372 S.

9. Stepanova, M. D., Fleischer, W. Grundzüge der deutschen Wortbildung. Leipzig: VEB Bibliographisches Institut, 1985. $241 \mathrm{~S}$.

10. Ule, C. H. Die Sprache in der Verwaltung. MS. 1960. (12). 427 S.

11. Weisberger, L. Von den Kräften der deutschen Sprache. Düsseldorf, 1954. 322 S.

\section{REFERENCES}

1. Nagamova, N. V. Ekzotsentricheskiye kompozity v nemetskom yazyke. [Exocentric composites in German]. Interuniversity collection of scientific papers: Bulletin of the Stavropol State University. 2007. Nr. 48. pp. 90-94 [In Russian].

2. Proshina, Z. G. Teoriya perevoda: uchebnik [Translation theory]. 2-e izd. Vladivostok: DVGU, 2002. 240 p. [In Russian].

3. Stepanova, M. D. Slovoobrazovaniye sovremennogo nemetskogo yazyka [Word formation of the modern German language]. Izd. 2-ye, ispr. M.: KomKniga, 2007. 376 p. [In Russian].

4. Talalay, T. S. Substantivnyye opredelitelnyye kompozity v tekstakh nemetskoy reklamy [Substantive determinative composites in the texts of German advertising]: avtoref. dis. ... kand. fil. n. 10.02.04. Ufa, 2011. 288 p. [In Russian].

5. Donalies, E. Basiswissen Deutsche Wortbildung. Tübingen: Narr Francke Attempto Verlag GmbH + Co. KG., 2007. 159 S. [In German].

6. Fleischer, W. Wortbildung der deutschen Gegenwartssprache. 1. Aufl. Leipzig: VEB Bibliographisches Institut, 1983. 272 S. [In German].

7. Hoffmann, L. Kommunikationsmittel Fachsprache. Eine Einführung. 2. überarbeitete Auflage. Berlin: AkademieVerlag, 1984. 431 S. [In German].

8. Polenz, P. Synpleremik I: Wortbildung. Lexikon der germanischen Linquistik. Tübingen: Max Niemeyer, 1973. 372 S. [In German].

9. Stepanova, M. D., Fleischer, W. Grundzüge der deutschen Wortbildung. Leipzig: VEB Bibliographisches Institut, 1985. 241 S. [In German].

10. Ule, C. H. Die Sprache in der Verwaltung. MS. 1960. (12). 427 S. [In German].

11. Weisberger, L. Von den Kräften der deutschen Sprache. Düsseldorf, 1954. 322 S. [In German]. 